\title{
NILAI BUDAYA MINANGKABAU DALAM \\ UNGKAPAN TRADISIONAL MASYARAKAT PASAMAN BARAT
}

\section{MINANGKABAU CULTURAL VALUE AT TRADITIONAL EXPRESSIONS BY PEOPLE OF PASAMAN BARAT}

\author{
Hasanadi \\ Balai Pelestarian Nilai Budaya (BPNB) Sumatera Barat \\ Jl. Raya Belimbing No 16 A Kuranji Kota Padang \\ e-mail: hasanassyahda@yahoo.co.id
}

\begin{abstract}
Abstrak
Tulisan ini membahas beberapa ungkapan tradisional Minangkabau yang digunakan masyarakat Kecamatan Pasaman Kabupaten Pasaman Barat. Beberapa ungkapan dimaksud adalah: (1) Ungkapan Simpang Tonang tajam sabalah; (2) Ungkapan teleang kupiah Rang Mandiangin; (3) Ungkapan Talu Rancak di labuah; (4) Ungkapan barek sabalah Nak Rang Talu; (5) Ungkapan kalam basigi lakuang batinjau; (6) Ungkapan tasingguang labiah bak kanai; (7) Ungkapan nak muliya tape'i janji. Dengan menggunakan pendekatan hermeneutik disimpulkan bahwa setiap ungkapan merefleksikan pesan budaya Minangkabau, yaitu: (1) Adil proporsional; (2) Berpikir lurus komprehensif; (3) Pentingnya kesesuaian antara hati dan perbuatan; (4) Berimbang; (5) Teliti dan tuntas; (6) Stabil emosi; (7) Tepat janji; (8) Teguh pendirian; (9) Cerdas lingkungan; dan (10) Beryukur dan berekspresi.
\end{abstract}

Kata kunci : Minangkabau, ungkapan tradisional, Kecamatan Pasaman

\begin{abstract}
This paper discusses some Minangkabau traditional expressions used by people of Pasaman Subdistrict, Pasaman Barat Regency. Some of the phrases are: (1) The phrase of "Simpang Tonang tajam sabalah"; (2) The phrase of "teleang kupiah Rang Mandiangin"; (3) The phrase of "Talu Rancak di labuah"; (4) The phrase of "barek sabalah Nak Rang Talu"; (5) The phrase of "kalam basigi lakuang batinjau"; (6) The phrase of "tasingguang labiah bak kanai"; (7) The phrase of "nak muliya tape'i janji"; (8) The phrase of "nak taguah paham dikunci"; (9) The phrase of "bak paneh dalam baluka"; dan (10) The phrase of "bak mandi di anak sungai". By using hermeneutic approach it is concluded each phrase reflects Minangkabau cultural message, namely: (1) Fair and proportional; (2) Thorough comprehensive thinking; (3) The importance of conformity between heart and deeds; (4) Balancing; (5) Thorough and thorough; (6) Stable emotion; (7) Exact appointment; (8) Firm stance; (9) Intelligent and well aware of milieu; and (10) Gratitude and expressive.
\end{abstract}

Key words: Minangkabau, traditional expression, Pasaman Sub-district 


\section{PENDAHULUAN}

Menurut Danandjaja (1991:191-229), upaya pendokumentasian atau pengarsipan folklor penting dilakukan. Ada tiga tahap yang harus dilakukan oleh seorang peneliti dalam upaya mendokumentasikan folklor, yaitu tahap prapenelitian, tahap penelitian dan tahap pembuatan naskah folklor. Apabila penelitian dilakukan terhadap folklor lisan yang teksnya terikat, seperti puisi, teka-teki bersajak, bidal, ungkapan tradisional atau peribahasa, pepatah, kata arif, pameo, pantun balada, epos dan lain sebagainya, maka harus dicatat dalam bahasa aslinya serta kemudian diberi dua macam terjemahan ke dalam bahasa Indonesia. Terjemahan pertama adalah terjemahan kata demi kata dan terjemahan kedua adalah terjemahan isi teks tersebut per kalimat.

Merujuk pada teknik dokumentasi folklor lisan sebagaimana ditawarkan oleh Danandjaja, berikut ini merupakan contoh dokumentasi yang dilakukan terhadap ungkapan tradisional Minangkabau yang tidak hanya digunakan oleh masyarakat di daerah luhak nan tigo, namun juga oleh masyarakat di Kabupaten Pasaman Barat Provinsi Sumatera Barat :

Ungkapan Tradisional-Sumatera-Minangkabau Simpang Empat Pasaman Barat.
Roma Sanwi, SS, 32,laki-laki

Wiraswasta, Minangkabau,

Indonesia.

Simpang Empat

25 September 2010

"Bak manapuak aia di dulang, tapacak muko sandiri"

"Bak menepuk air di dulang, terpercik muka sendiri"

"Menepuk dulang berisi air akan basah muka sendiri".

Ungkapan tradisional Minangkabau "bak manapuak aia di dulang, tapacak muko sandiri" dikenal Sanwi semenjak dia kanak-kanak, berusia sekitar 8 tahun. Dia sering mendengar orang bercerita serta kemudian menggunakan ungkapan tersebut untuk menyindir lawan bicara yang secara disengaja maupun tidak telah membuka aibnya sendiri.

Dulang adalah sejenis peralatan tradisional Minangkabau yang berfungsi sebagai tempat meletakkan kue atau cangkir kopi yang akan dihidangkan kepada tamu. Apabila dulang tersebut ditepuk maka air kopi di cangkir akan tumpah serta dapat membasahi wajah orang yang menghilangkannnya. Dia tentu akan merasa malu karena mengalami nasib buruk serta disaksikan oleh tamu.

Sanwi semakin memahami nilai budaya Minangkabau yang terdapat pada ungkapan "bak manapuak aia di dulang, tapacak muko sandiri", terutama setelah menjalani kuliah di Jurusan Sastra Daerah Fakultas Sastra Universitas Andalas. Menurutnya, ungkapan tersebut mengajarkan kewaspadaan dan sikap berhati-hati dalam menjaga martabat diri, keluarga dan kaum ketika berlangsungnya komunikasi dan interaksi di tengah masyarakat. Oleh karena itu, di tengah masyarakat Pasaman Barat yang multietnik ungkapan tersebut secara sekaligus berfungsi sebagai kontrol perilaku secara sosial-etnik, sehingga masyarakat yang hidup berdampingan serta memiliki etnik yang berbeda tetap bisa memelihara harmonisasi hubungan secara baik. 
Anotasi : Saydam, Gouzali : Kamus Lengkap Bahasa Minang. Cetakan ke-1, Padang, 2004, PPIM, hlm. 93.

Hasanadi, 37, Minang, laki-laki.

Komplek MGS III Blok C No. 1, Gunung Sarik, Padang.

Danandjaja menulis bahwa hasil dokumentasi sebagaimana penulis lakukan terhadap ungkapan tradisional "bak manapuak aia di dulang, tapacak muko sandiri" sebagai lembaran pengarsipan folklor. Dokumentasi tersebut, terlepas dari keberadaannya yang bisa menjawab kekhawatiran semakin sedikit masyarakat yang berkomunikasi dengan menggunakan ungkapan tradisional, juga mampu menjelaskannya kepada masyarakat tentang nilai budaya Minangkabau yang terdapat di dalamnya. Artinya, dokumentasi terhadap ungkapan tradisional Minangkabau menjadi penting tersedia, terutama agar ungkapan tradisional beserta nilai budaya yang direfleksikannya tidak terkondisi "menuju kepunahan".

Nilai budaya Minangkabau yang direfleksikan oleh ungkapan tradisional, khususnya yang digunakan oleh masyarakat Kecamatan Pasaman Kabupaten Pasaman Barat, merupakan warisan leluhur yang mesti diajarkan kepada genersi muda serta masyarakat secara umum. Berkenaan dengan itu, tidak terpungkiri bahwa usaha pelestarian ungkapan tradisional di daerah ini serta pewarisan nilai budaya Minangkabau yang terdapat di dalamnya, semakin tidak mendapat tempat di hati masyarakat. Sebagaimana dijelaskan Mangkuto (Budayawan Sumatera Barat), dewasa ini di Pasaman Barat, ungkapan tradisional Minangkabau beserta nilai budaya yang direfleksikannya hanya dikenal serta dipahami oleh tokoh masyarakat adat yang untuk konteks sosial budaya Minangkabau biasa dikenal dengan istilah "tungku tigo sajarangan" (Kongres Gebu Minang, 2011: 108-109). Sementara itu, masyarakat umum dan terutama kalangan generasi muda, semakin asing dengan ungkapan tradisional beserta nilai budaya Minangkabau yang direfleksikannya.

Di lain pihak, peneliti BPSNT Padang melalui kegiatan inventarisasi warisan budaya di Kabupaten Pasaman Barat yang dilakukan pada tahun 2010 berhasil menginventarisai sebanyak sepuluh warisan budaya takbenda (Seno, 2010: 80-81). Dari kesepuluh warisan budaya dimaksud tidak satu pun terkategori sebagai "bahasa sebagai wahana warisan budaya takbenda", khususnya kategori ungkapan tradisional. Kenyataan tersebut perlu untuk disikapi secara serius, salah satunya adalah dengan melakukan kegiatan penelitian secara lebih lanjut. Kenyataan bahwa masyarakat Pasaman Barat sebagian besarnya adalah bersukubangsa Minangkabau, yaitu diperkirakan sebesar 50\%, - selebihnya bersukubangsa Mandailing dan Jawa, tetap saja memunculkan asumsi bahwa Pasaman Barat kaya dengan ungkapan tradisional.

Tulisan ini, diramu ulang dari laporan penelitian dengan judul "Nilai Budaya Minangkabau dalam Ungkapan Tradisional Masyarakat Kabupaten Pasaman Barat Provinsi Sumatera Barat. Melalui tulisan ini diharapkan tersaji penjelasan tentang nilai budaya Minangkabau pada beberapa ungkapan tradisional yang digunakan oleh masyarakat Kecamatan Pasaman Kabupaten Pasaman Barat? 


\section{METODE PENELITIAN}

Tulisan ini diramu ulang berdasarkan hasil penelitian yang bersifat kualitatif. Penelitian kualitatif adalah penelitian yang bermaksud memahami fenomena tentang apa yang dialami subjek penelitian misalnya perilaku, persepsi, motivasi, tindakan, dan lain-lain, secara holistik dan dengan cara deskriptif dalam bentuk kata-kata dan bahasa, pada suatu konteks khusus yang alamiah dan dengan memanfaatkan berbagai metode ilmiah (Moleong, 2009: 2). Penelitian kualitatif menekankan pada quality atau hal terpenting dari sifat suatu barang/jasa. Hal terpenting dari suatu barang atau jasa berupa kejadian/fenomena/gejala sosial adalah makna dibalik kejadian tersebut yang dapat dijadikan pelajaran berharga bagi pengembangan konsep teori. Jangan sampai sesuatu yang berharga tersebut berlalu tanpa meninggalkan manfaat. Penelitian kualitatif diekplorasi dan diperdalam dari suatu fenomena sosial atau suatu lingkungan sosial yang terdiri atas perilaku, kejadian, tempat dan waktu (Satori dkk, 2009: 22). Proses pengumpulan data penelitian serta pengolahan data dan informasi dilakukan dalam beberapa teknik, yaitu observasi, wawancara, rekam, studi kepustakaan, dan analisis data. Setelah melakukan observasi, wawancara, perekaman, maka data primer berupa teks ungkapan tradisional dianalisis dengan menggunakan pendekatan hermeneutik.

Secara etimologis, hermeneutik besrasal dari kata hermeneuein, bahasa Yunani, yang berarti menafsirkan atau menginterpretasikan. Secara mitologis, pendekatan ini dikaitkan dengan dengan Hermes, nama Dewa Yunani yang menyampaikan pesan Ilahi kepada manusia. Pada dasarnya media pesan adalah bahasa, baik bahasa lisan maupun bahasa tulisan. Jadi, penafsiran disampaikan lewat bahasa, bukan bahasa itu sendiri. Teks sastra perlu ditafsirkan sebab di satu pihak ia terdiri atas bahasa, di pihak lain, di dalam bahasa sangat banyak makna yang tersembunyi, atau dengan sengaja disembunyikan (Ratna, 2004: 45).

Gagasan hermeneutik adalah dialektik antara pemahaman teks secara menyeluruh dengan interpretasi bagian-bagiannya yang apabila dideskripsikan menjadi bermakna karena diiringi penjelasan. Ini berarti, ada makna bagian-bagian teks yang ditarik atas dasar konteks yang kemudian dikembalikan pada aspek yang bersifat "keseluruhan". Hermeneutik adalah landasan filosofis yang juga merupakan salah satu modus dalam analisis data. Sebagai filosofi, hal ini menyediakan suatu landasan yang bersifat filosofis untuk kepentingan interpretasi. Hermeneutik berkaitan dengan upaya pemaknaan suatu analog teks; misalnya memahami organisasi atau kelompok sosial melalui pemaknaan cara lisan atau data tekstual. Pertanyaan mendasar adalah : apa arti dan makna teks itu ? Ini berarti, interpretasi adalah upaya untuk membuat jelas atau membuat studi bermakna. Oleh sebab itu, objek mesti kajian mesti dalam bentuk teks atau analog teks yang sepintas terlihat kabur serta terkadang saling bertentangan. Interpretasi bermaksud agar yang tidak jelas menjadi jelas untuk bisa dipahami. Interpretasi mesti menjadi kerangka berfikir dalam usaha memperjelas pengertian tersembunyi menjadi sesuatu yang bermakna dan jelas (Wiranta, 2007: 52).

Pendekatan hermeneutik memandang teks sastra dan filsafat sebagai objek kajian yang seyogianya disejajarkan dengan pendekatan interpretasi, pemahaman, versthen dan retroaktif. Dalam ilmu-ilmu sosial juga disebut metode kualitatif, analisis isi, alamiah, naturalistik, studi kasus, etnografi, etnometodologi dan fenomenologi serta biasanya dipertentangkan dengan metode kuantitatif (Maleong, 1989: 2). 
Pendekatan hermeneutik dipandang tepat untuk digunakan dalam menganalisis teks ungkapan tradisional yang dimiliki secara kolektif oleh masyarakat Kabupaten Pasaman Barat. Namun demikian, penggunaan hermeneutik tidak dimaksudkan untuk menghasilkan interpretasi yang bersifat paling tepat dan benar. Kenyataan tersebut didasarkan kenyataan bahwa setiap subyek peneliti dimungkinkan untuk memiliki titik berpijak yang berbeda. Penafsiran berbeda adalah suatu keniscayaan, karena setiap subyek akan memandang objek melalui horoson dan paradigma yang berbeda. Justru, keragaman pandangan pada gilirannya akan menghasilkan kekayaan makna terhadap teks ungkapan serta menambah kualitas estetika, etika dan logika sosial budaya terhadap teks ungkapan dimaksud.

\section{PEMBAHASAN}

\section{Selayang Pandang Kabupaten Pasaman Barat}

Kecamatan Pasaman merupakan salah satu kecamatan di Kabupaten Pasaman Barat Provinsi Sumatera Barat. Kabupaten Pasaman Barat sendiri merupakan salah satu dari 3 (tiga) Kabupaten Pemekaran di Propinsi Sumatera Barat, berdasarkan Undang-undang Nomor 38 Tahun 2003 tentang Pembentukan Kabupaten Dharmasraya, Solok Selatan dan Pasaman Barat. Kabupaten Pasaman Barat dengan luas wilayah 3.887,77 Km2, jumlah penduduk 388.893 jiwa dengan administrasi pemerintahan yang meliputi 11 (sebelas) kecamatan. Secara geografis Kabupaten Pasaman Barat terletak diantara 00o 33' Lintang Utara sampai 00o 11' Lintang Selatan dan 99o 10' sampai 100o 04' Bujur Timur. Batas administratif Kabupaten Pasaman

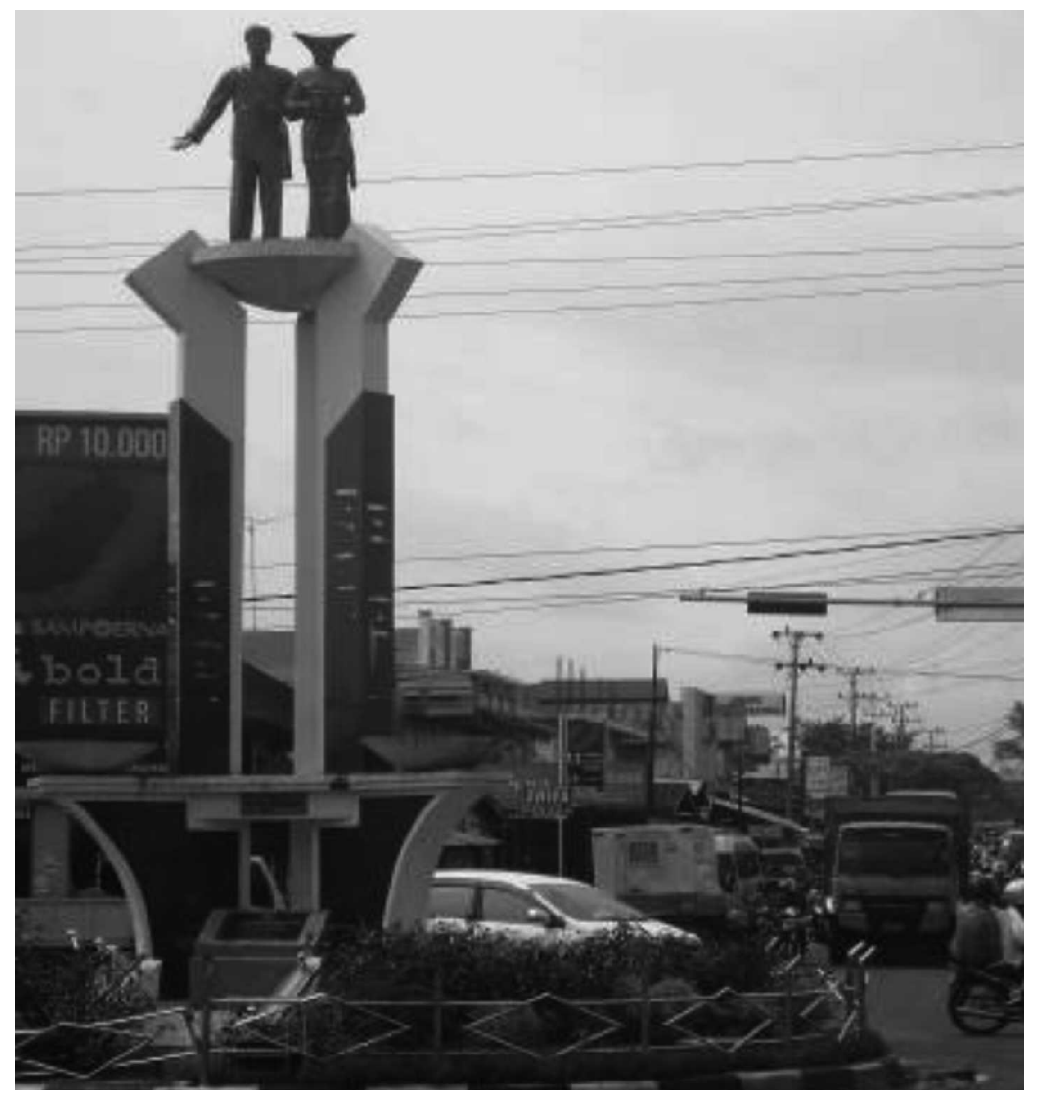

Tugu Bundaran Simpang Ampek di Kecamatan Pasaman 
Barat ; Sebelah Utara berbatasan dengan Kab. Mandailing Natal Sumatera Utara, sebelah Selatan berbatasan dengan Kabupaten Pasaman dan Kabupaten Agam Sumatera Barat, sebelah Barat berbatasan dengan Samudera Indonesia dan sebelah Timur berbatasan dengan Kabupaten Pasaman Sumatera Barat (Sumber : https://pasamanbarat.wordpress.com/pasaman-barat/, 9 April 2016).

Masyakat Pasaman Barat dalam kehidupan kesehariannya memakai bahasa Minangkabau dialek Pasaman, atau campuran bahasa Minangkabau dialek Pasaman dengan bahasa Batak (Mandailing), dan atau bahasa Batak (Mandailing) saja (Wawancara dengan Ilmi Yufa dan Roma Sanwi). Oleh karena itu, konteks kepemilikan dan penggunaan bahasa sebagaimana terjadi di daerah Pasaman Barat akan berkonsekuensi pada berbagai aspek kehidupan sosial budaya masyarakat. Demikian pula halnya, berbagai refleksi seni dan kesastraan pun menjadi sesuatu yang unik dan menarik (Yondri dkk, 2009: 13).

Kecamatan Pasaman meliputi 3 kenagarian yaitu :

1. Nagari Lingkuang Aua. Nagari meliputi 11 Kejorongan yaitu : Jorong Pasaman Baru, Jorong Kampung Cubadak, Jorong Simpang Empat, Jorong Katimaha, Jorong Bandarejo, Jorong Padang Durian Hijau, Jorong Jambak, Jorong Rimbo Binuang, Jorong Batang Biyu, Jorong Tanjung Pangka, Jorong Ribo Canduang.

2. Nagari Aur Kuning. Nagari ini meliputi 6 Kejorongan yaitu: Jorong Padang Tujuh, Jorong Pinagar, Jorong Suka Menanti, Jorong Lubuk Landur, Jorong Lembah Binuang, Jorong Bukik Nilam,

3. Nagari Aia Gadang, meliputi 3 Kejorongan yaitu: Jorong Aia Gadang Barat, Jorong Aia Gadang Timur, Jorong Labuah Luruih. II. Kecamatan Luhak Nan Duo

Lingkuang Aua adalah sebuah nagari di Kecamatan Pasaman, Kabupaten Pasaman Barat. Nagari ini memiliki luas 213,45 km² serta didiami oleh sekitar 25.029 jiwa penduduk. Beberapa jorong di Nagari Lingkuang Aya adalah, Bandarjo, Batang Biyu, Jambak, Kampuang Cubadak, Katimaha, Padang Hijau, Pasaman Baru, Rimbo Binuang, Rimbo Janduang, Simpang IV, dan Tanjuang Pangkal. Seiring adanya program pemekaran pemerintah nagari di Pasaman Barat, Nagari Lingkuang Aua yang berlokasi dipusat ibukota kabupaten di sebut-sebut akan mekar pula menjadi 9 Nagari. Tak ayal rencana pemekaran nagari yang berlokasi di pusat kota Pasbar ini mendapat sambutan hangat dari sejumlah tokoh masyarakat nagari. Sebab pemekaran nagari tersebut dinilai sebagai langkah tepat untuk meningkatkan pelayanan publik, serta dapat membuat hubungan masyarakat dengan aparat pemerintah nagari lebih dekat (Rencana Pembangunan Jangka Menengah (RPJM) Nagari Lingkuang Aua Tahun 2016-2021).

Sebagaimana disampaikan Maizal (wawancara tanggal 13 Maret 2016), sesuai langkah kerja pemerintah pusat saat ini dan seiring bertambah banyaknya penduduk di berbagai nagari yang ada di Pasaman Barat, termasuk untuk Nagari Lingkuang Aua, maka sangat memungkinkan Nagari Lingkuang Aua dimekarkan. Semoga dana yang di janjikan pemerintah Rp 1 miliar perdesa/nagari, kian banyak pula kuncuranya ke Pasaman Barat. Kalau Nagari Lingkuang Aua dimekarkan menjadi 9 nagari/desa, kontan setiap tahun Nagari Lingkuang Aua akan tersentuh 
dana Rp 9 miliar setiap tahun. Dengan itu masyarakat akan cepat diberdayakan dan pembangunan fisik menjamur. Sesuai rapat yang diikutinya di Kantor Walinagari Lingkuang Aua beberapa hari sebelumnya. Wacana pemekaran Nagari Lingkuang Aua adalah, Jorong Rimbo Janduang dan Pasaman Baru akan menjadi satu nagari, Jorong Rimbo Binuang dan Kampuang Cubadak menjadi satu nagari, Jorong Siampang Ampek menjadi 2 nagari, Jorong Banda Rejo menjadi 1 nagari, Jorong Padang Durian Hijau dan Jambak menjadi 1 nagari, Jorong Katimaha dan Jorong Batang Biyu 1 nagari dan Jorong dan Gorong Tanjuang menjadi satu nagari pula.

Berdirinya Nagari Aia Gadang bermula dari cerita tentang satu daerah yang subur, tumbuhan yang menghijau di atas tanah yang datar serta dikelilingi oleh semak yang lebat. Daerah tersebut dialiri beberapa sungai besar, di antaranya Batang Pasaman, Batang Tongar, Batang Lingkin, Batang Kenaikan dan Batang Unpai. Semua aliran sungai tersebut bermuara ke batang Pasaman. Di tepi sungai inilah hidup kelompok masyarakat yang rukun dan damai. Pada masa itu, Batang Pasaman sebagai urat nadi transportasi dengan menggunakan perahu/ sampan serta membawa hasil tani untuk memenuhi kebutuhan hidup sehari-hari. Batang Pasaman, ketika musim hujan sering mengalami banjir, paling sedikit dua kali dalam satu tahun. Banjir tersebut berdasarkan pemahaman dan bahasa penduduk setempat disebut dengan "aia gadang”. Mulai tahun 1954 masyarakat yang tinggal di tepi Sungai Batang Pasaman berangsur pindah ke daratan. Pemerintah pun membuat jalan lintas Sumatera dan terus berkembanglah penduduk di daerah tersebut. Nagari Aia Gadang pun berdiri, tepatnya di tepi jalan raya, perbatasan Nagari Lingkuang Aua dan Nagari Muara Kiawai. (RPJM Nagari Aia Gadang Tahun 2016-2021).

Nagari Aia Gadang memiliki luas 130,4 Km², berjumlah penduduk 5.040 jiwa. Kepadatan penduduk di nagari ini adalah $29 \mathrm{jiwa} / \mathrm{km}^{2}$. Nagari ini berbatas dengan, sebelah Utara berbatas dengan Nagari Muara Miawai, sebelah Selatan berbatas dengan Nagari Lingkuang Aua, sebelah Barat berbatas dengan Nagari Lingkuang Aua dan sebelah Timur berbatas dengan Nagari Linkuang Aua. Terdapat 6 (enam jorong di Nagari Aia Gadang, yaitu :

1. Jorong Batang Lingkin

2. Jorong Tongar

3. Jorong Batang Umpai

4. Jorong Durian Hutan

5. Jorong Pasia Bintungan

6. Jorong Labuah Luruih

Secara topografi Nagari Aia Gadang memiliki kemiringan lahan datar 130, 4 Km serta dengan ketinggian di atas permukaan laut $14 \mathrm{M}$. Jumlah penduduk usia produktif di nagari ini lebih banyak disbanding usia anak-anak dan lansia. Perbandingan usia anak-anak, usia produktif dan lansia adalah, $21 \%: 61 \%: 18 \%$. Dari jumlah penduduk yang berada pada kategori usia produktif laki-laki dan perempuan jumlahnya hamper sama. Mata pencarian mayoritas warga Nagari Aia gadang adalah petani dan buruh tani. Hal ini disebabkan karena sejak turun temurun nenek moyangnya adalah petani. Mayoritas warga Nagari Aia Gadang beragama Islam. Penting juga ditulis terkait program pembangunan Nagari Aia Gadang bahwa, secara sosial budaya di 
Nagari Aia Gadang telah berdiri taman bacaan masyarakat dan balai pelatihan/kegiatan belajar masyarakat (RPJM Nagari Aia Gadang Tahun Rencana Pembangunan 2016-2021, 2015).

Nagari Aua Kuniang memiliki luas133,45 km², berjumlah penduduk 8.394 jiwa. Kepadatan penduduk nagari ini 63 jiwa/ $/ \mathrm{km}^{2}$. Pada tanggal 7 Januari 2004 Nagari Aua Kuniang termasuk salah satu dari enam Nagari di Kabupaten Pasaman, yaitu Nagari Aia Gadang, Aua Kuniang, Lingkungan Aua, Sasak, Kapar dan Nagari Koto Baru. Tetapi setelah pemekaran Nagari Aua Kuniang merupakan satu Nagari dari 19 Nagari di KabupatenPasaman Barat. Sebagai Nagari, Aua Kuniang terdiri dari enam Jorong, yaitu Jorong inaga, Padang Tujuh, Sukamenanti, Lubuak Landua, Lembah Binuang dan Bukit Nilam. Kemudian berdasarkan UU No. 5tahun 1979 tentang pemerintahan Desa maka Nagari Aua Kuniang berubah menjadi Desa,. Pemerintahan Desa yang diamanatkan dalam UU No. 5 tahun 1979 menggantikan Nagari dan berfungsi sebagai perpanjangan tangan dari pemerintahan pusat, Provinsi dan Kabupaten (BPS Kabupaten Pasaman Barat Tahun 2005:39).

Di Sumatera Barat dengan adanya semangat reformasi, berkembang aspirasi ingin memfungsikan kembali unit pemerintahan Nagari yang selama ini telah hilang. Gencarnya semangat kembali ke Nagari mempunyai makna tersendiri bagi masyarakat Minangkabau. Hal ini sesuai dengan dikeluarkannya Peraturan Daerah Provinsi Sumatera Barat No. 9 tahun 2000 tentang ketentuan pokok pemerintahan yang memuat ketentuan-ketentuan yang mengatur tentang pemerintahan Nagari. Dengan beralihnya ke sistem pemerintahan Nagari, khususnya Nagari Aua Kuniang mengakibatkan adanya dampak yang terjadi, misalnya mempengaruhi peran Tungku Tigo Sajarangan dan juga masyarakat tidak lagi mengadu dan membawa persoalan dalam kaum atau ke Tungku Tigo Sajarangan, masyarakat langsung berhubungan dengan polisi dan pengadilan-pengadilan lainnya. Dampak yang lain juga terjadi adanya konflik antara perangkat Desa yang mana ia tidak setuju karena dengan beralihnya ke sistem pemerintahan Nagari ia tidak dilibatkan dalam perangkat Nagari (Asnawi, 2009).

Surau Lubuak Landua Nagari Aua Kuniang Kecamatan Pasaman Barat merupakan salah satu surau tertua yang ada di Pasaman Barat (Pasbar) yang ada sejak tahun 1921. Meskipun demikian, Surau ini hingga saat ini tetap eksis yang sudah dikenal sejah dahulu kala sebagai salah satu surau tempat pengembangan agama Islam. Melihat bangunan surau Lubuak Landua seolah-olah kita tidak percaya bahwa usia Surau ini sudah berumur lebih kurang 88 tahun. Dengan usia yang sudah mendekati satu abad, surau ini tetap kokoh berdiri meskipun masih berdindingkan papan. Bangunan ini sekokoh semangat untuk mengembangkan ajaran Agama Islam di Pasaman Barat. Menurut sejarah kabarnya penyebaran agama Islam di Pasaman Barat salah satunya berada di Lubuak Landua. Dan ini dibuktikan dengan sejarah surau tua yang masih tetap berdiri kokoh yang hingga saat ini menjadi tempat masyararakat belajar agama Islam dan belajar silat yang keduanya tidak bisa dipisahkan di dalam belajar agama Islam sejak dulu kala (Sumber: http://www.antarasumbar.com/berita/134299/titik-awal-penyebaran-islamdi-pasaman-barat.html, diunduh taggal 9 April 2016).

Gunung Talamau terletak di Jorong Pinaga, Nagari Aua Kuniang, Kecamatan Pasaman, Kabupaten Pasaman Barat. Gunung Talamau dengan ketinggian 2982 meter dari permukaan 
laut (dpl), merupakan gunung tertinggi di Provinsi Sumatera Barat. Karakteristik Gunung Talamau termasuk salah satu dari gunung api, tetapi Talamau termasuk gunung yang tidak aktif. Gunung tersebut menyimpan segudang pesona yang sayang tuk di lewatkan. Kawasan hutan yang masih perawan, ditingkahi kicauan burung yang bersahutan berpadu dengan keindahan puluhan telaga yang terserak di kawasan gunung, membuat perjalanan panjang para wisatawan takkan terasa sia-sia. Berdasarkan hasil penelitian Pusat Penelitian Geoteknologi Lembaga Ilmu Pengetahuan Indonesia (LIPI), Gunung Talamau berasal dari berbagai jenis batuan, yaitu batuan vulkanik produk Galau (campuran) Talamau, yang dari Major Elemen yang menunjukkan batuan beku di kawasan itu dapat dibedakan menjadi empat macam yaitu jenis batuan basa (basalt), menengah (andesit), agak asam (dasit), dan granit (asam) (Sumber:http://www.kompasiana.com/sulpandri/sejarah-nagari-sungai-aua-kabupaten Pasamanbarat, diunduh taggal 23 Maret 2016).

Berdasarkan keterangan Dt. Putiah (wawancara tanggal 12 Maret 2016), terdapat dua versi cerita terkait dengan proses sejarah penamaan Nagari Aua Kuniang. Versi pertama, nama Nagari Aua Kuniang berasal dari nama serumpun bambu berduri berwarna kuniang. Konon, disekitar rumpun bambu itulah para ninik moyang mengadakan pertemuan pada suatu hari. Versi kedua, pada zaman dahulu, sesudah nenek moyang berhasil mendirikan taratak, mereka pun mengadakan pertemuan. Salah satu tujuan pertemuan tersebut adalah untuk menyepakati perihal nama yang akan diberikan pada tempat bermukim mereka kelak. Disepakatilah pada pertemuan itu bahwa, nama Nagari Aua Kuniang diambil dari kata "dikuniangan nasi”. Sebagai istilah "dikuniangan nasi” berarti memasak nasi kunyit serta memakannya bersama-sama sebagai perwujudan suka cita setelah berhasil membuat satu keputusan. Biasanya, belum akan dianggap sempurna sebuah kesepakatan atau hasil sebuah pekerjaan sebelum mereka memasak nasi kunyit".

\section{Ungkapan Tradisional dan Refleksi Budaya Minangkabau}

10 (sepuluh) ungkapan tradisional yang digunakan oleh masyarakat Kecamatan Pasaman serta berhasil didokumentasi adalah : (1) Simpang Tonang tajam sabalah; (2) Teleang kupiah Rang Mandiangin; (3) Talu rancak di labuah; (4) Barek sabalah nak Rang Talu; (5) Kalam basigi lakuang batinjau; (6) Tasingguang labiah bak kanai; (7) Nak muliya tape'i janji; (8) Nak taguah paham dikunci; (9) Bak paneh dalam baluka; (10) Bak mandi di anak sungai. Dokumentasi ungkapan tradisional mengacu pada upaya pendokumentasian folklor sebagaimana dilakukan oleh Danandjaja. Berikut penjelasan nilai budaya Minangkabau yang direfleksikan oleh kesepuluh ungkapan tersebut :

\section{Ungkapan Simpang Tonang Tajam Sabalah}

Ungkapan Tradisional-Sumatera-Minangkabau Lingkuang Aua Pasaman Barat.
Dt. St. Kabasaran, 60, laki-laki

Ketua KAN, Minangkabau,

Indonesia.

Lingkuang Aua

15 Maret 2016 


\section{"Simpang Tonang tajam sabalah" \\ "Simpang Tonang tajam sebelah" \\ "Orang Simpang Tonang tidak adil"}

Simpang Tonang merupakan salah satu nama nagari di Kabupaten Pasaman Barat. Menurut maestro, ungkapan "Simpang Tonang tajam sabalah" digunakan untuk menyebut sikap dan perilaku sebagian anak nagari Simpang Tonang yang inginnya menang sendiri. Sikap dan perilaku tersebut tentunya berimplikasi pada adanya kecenderungan untuk mengabaikan kepentingan serta urusan orang lain, yaitu orang-orang yang berasal dari luar Nagari Simpang Tonang. Sikap dan perilaku ingin menang sendiri serta cenderung bersikukuh dengan pendapat yang dikemukakan, meskipun terbukti bahwa pendapat tersebut jauh dari kebenaran, kemudian menjadi faktor kuat munculnya ungkapan Simpang Tonang tajam sabalah”.

Terutama pada masa lampau, mengacu pada ungkapan ini "Simpang Tonang tajam sabalah”, warga Simpang Tonang dinilai sangat egois serta tidak peduli dengan nasib yang menimpa orang lain. Mereka terbiasa mengungkit kesalahana orang lain namun berupaya untuk selalu berdiam diri apabila kesalahan tersebut bersumber dari diri sendiri. Mereka dikenal kritis dalam menyoroti urusan orang lain namun cenderung membisu terkait dengan urusan mereka sendiri.

Secara sosial budaya, khususnya di Pasaman Barat, ungkapan "Simpang Tonang tajam sabalah" telah memunculkan stigma negatif terhadap warga Simpang Tonang. Terutama berlangsung di masa lampau, pengaruh ungkapan ini telah menjadikan warga Simpang Tonang dijauhi dalam pergaulan. Kondisi tersebut mengkondisikan sulitnya warga Simpang Tonang untuk menjalin hubungan baik dengan warga luar. Pengalaman pahit yang dirasakan oleh banyak orang ketika berurusan dengan warga Simpang Tonang pun seakan meninggalkan bekas yang nyata hingga masa sekarang.

Apabila menyebut Simpang Tonang, maka yang akan muncul adalah defenisi bahwa para warganya adalah orang-orang yang egois. Oleh karena itu, dianggap perlu upaya untuk memperbaiki citra Simpang Tonang, sehingga proses sosialisasi dengan warga sekitar dapat berjalan lebih baik. Masyarakat di daerah ini memerlukan upaya nyata dalam meyakinkan orangorang luar bahwa Simpang Tonang juga memiliki orang-orang yang mampu berlaku adil.

Para orang tua Simpang Tonang juga harus memastikan warga sekitar bahwa anak-anak mereka di masa sekarang terus bertumbuh dengan semangat untuk memperjuangkan nilai-nilai keadilan. Para generasi muda, terutama ketika berinteraksi dengan pemuda luar, misalnya dalam berbagai kegiatan kepemudaan, mesti pula mampu menunjukkan bahwa mereka mampu berubah kea rah yang lebih baik serta mampu berlaku secara adil.

Stigma negatif sebagaimana diisyaratkan oleh ungkapan "Simpang Tonang tajam sabalah" mesti diperbaiki serta diubah sehingga Simpang Tonang di masa yang akan datang adalah daerah yang dihuni oleh orang-orang adil dalam setiap kegiatan yang diikuti. Peran aktif pemerintah daerah Pasaman Barat dalam memperbaiki citra "Simpang Tonang tajam sabalah" perlu juga ditingkatkan, sehingga kehidupan sosial bermasyarakat di Pasaman Barat secara keseluruhan terus berjalan sesuai dengan yang diharapkan. 
Hasanadi, 37, Minang, laki-laki.

Komplek MGS III Blok C No. 1, Gunung Sarik, Padang.

\section{Ungkapan Teleang Kupiah Rang Mandiangin}

Ungkapan Tradisional-Sumatera-Minangkabau Dt. St. Kabasaran, 60, laki-laki

Lingkuang Aua Pasaman Barat.

Ketua KAN, Minangkabau,

Indonesia.

Lingkuang Aua

15 Maret 2016

\section{"Teleang kupiah rang Mandiangin" \\ "Miring kopiah/peci orang Mandiangin" \\ "Miring peci orang mandiangin"}

Berdasarkan keterangan maestro, Katiagan Mandiangin merupakan salah satu nagari yang ada di Kecamatan Kinali, Kabupaten Pasaman Barat. Nagari ini terletak di bagian Selatan Kabupaten Pasaman Barat, atau sekitar 50 kilometer dari Simpang Ampek. Sebelah utara berbatasan dengan Nagari Sasak Ranah Pasisie, sebelah Selatan dengan Nagari Tiku Kabupaten Agam, sebelah Timur dengan Nagari Kinali dan sebelah Barat dengan Samudra Hindia. Nagari Katiagan Mandiangin dihuni oleh sekitar empat ribu jiwa dengan tiga ratusan Kepala Keluarga (KK). Sebagian besar masyarakatnya bermata pencaharian sebagai nelayan dan petani kebun. Sebagian besar lahan di wilayah Katiagan adalah lahan perkebunan dengan luas sekitar delapan ribu Ha. Penduduknya 100 persen menganut agama Islam dan etnis yang mendominasi adalah suku Minangkabau. Sisanya adalah suku Mandailing dan suku Jawa.

Sebagai penanda identitas bagi orang luar warga Mandiangin tradisional ternyata memiliki keunikan perilaku dalam berpakaian, khususnya ketika memasangkan atau memakai peci (kopiah/kupiah) di kepala. Keunikan dalam memakai atau memasangkan peci tersebut terlihat dari kecenderungan bahwa, peci tersebut dipasang miring di atas kepala. Terutama menjadi kebiasaan kaum laki-laki dewasa, peci akan terpasang miring di kepala mereka, namun tetap dalam posisi pasang yang kokoh. Dengan kata lain, meskipun peci tersebut terpasang miring (teleang) peci di kepala orang Mandiangin tidak mudah jatuh.

Kokohnya pasang peci orang Mandiangin relatif sama dengan kekokohan pasang peci sebagaimana biasanya tampak pada laki-laki dewasa di Minangkabau umumnya. Peci/kopiah terpasang secara seimbang di kepala, tidak miring ke kiri, ke kanan, ke depan atau ke belakang. Keunikan cara dan perilaku dalam memakai atau menggunakan peci sebagaimana dilakukan oleh orang Mandiangan kemudian menjadi karakteristik yang ikut mempengaruhi persepsi orang luar tentang orang Mandiangin.

Berdasarkan penjelasan maestro, sesungguhnya kebiasaan memakai atau menggunakan peci di kepala sebagaimana dilakukan orang Mandiangin, dapat dijelaskan dalam beberapa aspek. Pertama, meskipun terkesan gampangan atau slengean, kebiasaan tersebut dapat 
menggambarkan sikap dan perilaku santai orang Mandiangin dalam menjalani kehidupan. Kesan gampangan tersebut sekaligus memunculkan persepsi bahwa orang Mandiangin mampu menghadapi berbagai persoalan dengan sikap sederhana dan bersahaja. Persepsi tersebut tentu saja juga terkait dengan tipikal orang Mandiangin ketika berinterasi dengan orang luar. Artinya, orang-orang Mandiangin tidak akan mengubah posisi peci yang telah terpasang miring meskipun mereka tengah berkomunikasi serta berurusan dengan orang-orang luar. Orang Mandiangin akan tetap tampil sebagaimana adanya mereka berpakaian, khususnya terkait dengan kebiasaan memakai peci dalam posisi miring.

Kedua, bagian kepala merupakan organ tubuh yang dianggap paling penting, termasuk oleh masyarakat Pasaman Barat secara keseluruhan. Sehingga, jenis pakaian yang dilekatkan di kepala, cara pakai termasuk pilihan waktu dan tempat dalam memakai, akan sangat mempengaruhi persepsi masyarakat tentang pola pikir serta khasanah pengetahuan yang dimilki oleh seseorang. Oleh karena itu, persepsi negatif juga tidak bisa diabaikan berkenaan dengan kebiasaan orang Mandiangin dalam memakai atau menggunakan peci.

Bagi sebagian warga kebiasaan tersebut justru dipersepsi bahwa orang Mandiangin memiliki kecenderungan berpikir yang tidak baik. Menurut mereka, kebiasaan tersebut mengimplikasikan bahwa orang Mandiangin tidak elegan dalam berpakaian. Pendapat, pemikiran serta kata-kata orang Mandiangin sulit untuk dipegang. Ungkapan "teleang kopiah orang Mandiangin" sekaligus mengindikasikan "tidak lurus/tidak seimbang/tidak koprehensif" nya pikiran mereka.

Ketiga, kebiasaan memakai peci di kepala sebagaimana ditunjukkan oleh orang Mandiangin, juga memunculkan kesan bahwa orang-orang Mandiangin sulit untuk diajak serius. Kesan tersebut dinilai wajar karena pakaian yang sedang melekat di tubuh tentunya akan ikut memberi gambaran tentang suasana psikologis seseorang. Oleh karena itu, ketika berhadapan dengan suatu permasalahan yang dianggap serius, orang-orang Mandiangin justru dinilai tidak mampu memperlihatkan keseriusan. Sebagaimana terlihat dari cara berpakaian mereka, maka yang akan muncul adalah pandangan kurang baik dari orang banyak. Namun demikian, terlepas dari semua kesan dan penjelasan terkait dengan ungkapan "teleang kupiah orang Mandiangin", kebiasaan dalam perilaku berpakaian tersebut telah menjadi penanda identitas kolektif orang Mandiangin, terutama pada kehidupan tradisional mereka di masa lampau.

Di kehidupan orang Mandiangin pada masa sekarang tentunya segala persepsi negatif tersebut harus terus ditepis, yaitu dengan sikap rendah hati melakukan berbagai perbaikan diri. Di masa sekarang, cara berpakaian, cara bertutur kata, serta cara bergaul dengan warga sekitar, yang terus membaik dan berterima di mata orang banyak, merupakan syarat penting bagi perubahan persepsi masyarakat Pasaman Barat terhadap orang Mandiangin.

Hasanadi, 37, Minang, laki-laki.

Komplek MGS III Blok C No. 1, Gunung Sarik, Padang. 


\section{Ungkapan Talu Rancak di Labuah}

Ungkapan Tradisional-Sumatera-Minangkabau Lingkuang Aua Pasaman Barat.
Dt. St. Kabasaran, 60, laki-laki

Ketua KAN, Minangkabau,

Indonesia.

Lingkuang Aua

15 Maret 2016

\section{"Talu rancak di labuah" \\ "Talu elok/indah di jalan/di luar" \\ "Talu hanya elok/indah di jalan/di luar"}

Kata maestro, nama Talu mungkin sudah tak asing lagi bagi warga Sumatra Barat, terutama karena adanya judul lagu Minang "Rang Talu”, atau legenda Kuburan Duo. Sebenarnya ada hal-hal menarik lain dari nagari yang termasuk Kenagarian Talu, Kecamatan Talamau, Kabupaten Pasaman Barat ini. Misalnya pemandangan Gunung Talamau, arus deras di Batang Talu dan Batang Sinuruik, permandian air panas, air terjun dan sebagainya. Dengan mobil, Talu bisa dicapai dalam waktu sekitar 4 jam. Berangkat pukul 07.30 WIB dari Simpang Empat Pasaman Barat, sampai pukul 11.30 WIB. Lebih dari itu, yang lebih menarik dari Talu dan Sinuruik adalah suasana kesehariannya yang sangat kental nuansa tradisionalnya.

Begitu pula dengan ungkapan "Talu rancak di labuah", khususnya berlaku bagi masyarakat Talu tradisional, paling tidak telah memberikan gambaran bahwa orang Talu akan mampu menampilkan diri secara elok/indah ketika berada di jalan atau di luar. Gambaran tersebut betolak dari defenisi sederhana bahwa kata "rancak" dalam ungkapan lebih diartikan "elok/ indah" sementara kata "di labuah" diartikan sama dengan "di jalan/di luar".

Sebaliknya, kilas balik tentang orang Talu sebagaimana diisyaratkan oleh ungkapan dimaksud berarti juga memberi penjelasan bahwa orang Talu relatif tidak mampu menjaga penampilan ketika mereka berada di rumah. Dengan kata lain, penampilan orang Talu ketika mereka berada di jalan atau di luar - terlihat elok dan indah, tidak akan sama dengan penampilan mereka ketika berada di rumah. Tambahan lagi, berarti pula orang Talu hanya mementingkan persoalan penampilan ketika mereka ke luar atau sedang berada di tangah khalayak. Sebaliknya, ketika mereka di rumah atau sedang tidak berada di hadapan orang banyak, maka mereka akan tampil secara biasa-biasa saja—bisa jadi justru tampil secara tidak rapi.

Maestro juga menjelaskan bahwa ungkapan "Talu rancak di labuah” tidak hanya bercerita tentang penampilan orang Talu di jalan/di luar dan di rumah. Ungkapan tersebut juga menggambarkan bagaimana sesungguhnya orang Talu dalam menempatkan dirinya sebagai bagian dari orang lain dan masyarakat secara luas. Oleh karena itu, sesungguhnya melalui ungkapan tersebut dapat ditemukenali karakter dan kepribadian orang Talu.

Pertama, ungkapan "Talu rancak di labuah" sesungguhnya telah memperkenalkan orang Talu sebagai pribadi dan kelompok sosial yang baik dan indah dari aspek penampilan namun relatif "buruk" dalam bersikap dan berperilaku. Artinya, penampilan orang Talu yang elok dan indah bukanlah kenyataan yang juga akan dapat ditemukan dalam sikap dan perbuatan mereka. 
Elok dan indahnya penampilan orang Talu bukan berarti juga mengindikasikan elok dan indahnya perbuatan dan akhlak mereka.

Selanjutnya, ungkapan “Talu rancak di labuah” sekaligus telah memunculkan persepsi bahwa orang Talu bukanlah pribadi dan kelompok sosial yang jujur. Penampilan elok dan indah orang Talu hanyalah topeng yang dipakai serta dimaksudkan untuk menutupi segala kelemahan atau ketidakmampuan mereka dari orang lain. Pakaian indah dan penampilan mereka yang rapi ketika berhadapan dengan orang banyak misalnya, bukanlah indikasi bahwa mereka memang betul-betul memiliki kekayaan yang banyak. Tampilan ramah mereka ketika bertutur dan berkomunikasi dengan orang lain bukanlah penjelasan kongkrit serta jujur untuk hati dan pemikiran mereka yang sebenarnya. Karena itu pula, adalah wajar ketika pilihan sikap yang diperlihatkan orang lain ketika bergaul dengan orang Talu adalah lebih berhati-hati serta tidak mudah terpengaruh oleh penampilan atau sikap ramah yang diperlihatkan.

Secara sosial budaya, khususnya di Pasaman Barat, ungkapan "Talu rancak di labuah" beserta segala implikasi dan persepsi yang muncul mengajarkan pentingnya kesesuaian antara hati dan perbuatan. Ketidaksesuaian antara apa yang ada di dalam hati dan pikiran dengan apa yang ditunjukan melalui perbuatan justru akan memunculkan sikap antipati dari lingkungan sosial.

Di samping itu, nilai budaya ungkapan "Talu rancak di labuah" sekaligus mengajak semua orang untuk tidak sekedar berfokus pada penampilan fisik namun juga terhadap tampilan psikologis yang tentunya akan dapat dicermati dari pilihan-pilihan sikap dan perilaku sosial yang ditunjukkan. Implikasi sosial budaya ungkapan "Talu rancak di labuah" pada gilirannya akan menjadi bukti bahwa bukanlah penampilan yang pada akhirnya menjadikan seseorang eksis di tengah masyarakat. Namun sebaliknya, eksistensi setiap individu dalam konteks sosial budaya masyarakat sangat ditentukan oleh adanya kesesuaian antara penampilan dan perkataan dengan sikap dan perbuatan.

Hasanadi, 37, Minang, laki-laki.

Komplek MGS III Blok C No. 1, Gunung Sarik, Padang.

\title{
4. Ungkapan Barek Sabalah Nak Rang Talu
}

Ungkapan Tradisional-Sumatera-Minangkabau Dt. St. Kabasaran, 60, laki-laki

Lingkuang Aua Pasaman Barat. Ketua KAN, Minangkabau, Indonesia. Lingkuang Aua

15 Maret 2016

\author{
"Barek sabalah nak rang Talu" \\ "Berat sebelah anak orang Talu" \\ "Tidak adil anak orang Talu"
}


Menyimak penjelasan maestro, ungkapan "barek sabalah nak rang Talu” mengisyaratkan tipikal serta kepribadian warga Pasaman Barat, khususnya yang mendiami daerah Talu, yang tidak jujur serta tidak adil. Tipikal kepribadian sebagaimana disebut dalam ungkapan ini tentunya lahir dari konteks sosial budaya masyarakat Talu tradisional. Relevansi penggunaan ungkapan ini terhadap orang Talu tentunya pula layak dikritisi serta dibuktikan secara baik.

Bahwa pada masa lampau orang Talu dianggap sebagai pribadi serta kelompok sosial yang tidak adil tentunya memerlukan klarifikasi secara profesional. Oleh karena itu, harapan maestro, biarlah ungkapan ini menjadi bagian dari khasanah ungkapan lisan masyarakat Pasaman Barat zaman dahulu, sehingga keberadaannnya di masa sekarang tidak mesti menjadi perdebatan yang berujung pada munculnya konflik antara orang Talu dengan orang luar.

Kembali pada ungkapan, terutama dalam berbagai urusan yang melibatkan orang Talu dengan warga luar, maka orang Talu dipersepsikan sebagai orang yang tidak adil atau bersikap berat sebelah. Si orang Talu lebih mementingkan diri dan kelompoknya serta mengabaikan kepentingan orang lain. Menurut maestro, persepsi tersebut tentunya tidak muncul dengan sendirinya. Sebagai sebuah persepsi, apalagi kemudian diabadikan dalam sebuah ungkapan yang masih dikenal hingga masa sekarang, ia muncul atas dasar pengalaman berulang warga sekitar ketika berurusan dengan orang Talu.

Disepakati atau tidak yang jelas ungkapan "barek sabalah nak rang Talu” telah menjadi penanda bagi identitas kolektif masyarakat Talu hingga masa sekarang. Oleh karena itu, yang perlu dilakukan adalah membuktikan bahwa persepsi tersebut tidak benar, serta mesti dilakukan oleh orang Talu dimanapun mereka berada.

Secara sosial budaya, penggunaan ungkapan "barek sabalah nak rang Talu” tentunya akan memunculkan persoalan di masa sekarang. Maestro mensinyalir bahwa penggunaan ungkapan ini pada masa sekarang akan dapat memunculkan konflik sosial. Namun sebagai bahan renungan bagi masyarakat Pasaman Barat ungkapan ini layak menjadi perhatian. Paling tidak, adanya ungkapan ini mengingatkan warga Pasaman Barat agar berhati-hati dalam bersikap dan berperilaku, sehingga stigma negatif senantiasa terhindar dari kehidupan mereka.

Lebih penting lagi, sebagai refleksi, generasi masa depan Pasaman Barat tidak selayaknya mewarisi anggapan serta persepsi yang buruk sebagai akibat perlakuan buruk masyarakat di masa sekarang. Di masa dewasa mereka nanti yang dibutuhkan adalah kepercayaan diri dalam membangun komunikasi dan interaksi dengan orang lain. Sehingga, berbagai sikap dan perilaku tidak baik yang akan menghalangi mereka dalam berkomunikasi dan berinteraksi dengan orang lain di masa depan mesti dijauhkan sejauh-jauhnya dari kehidupan orang Talu di masa sekarang.

Hasanadi, 37, Minang, laki-laki.

Komplek MGS III Blok C No. 1, Gunung Sarik, Padang. 


\section{Ungkapan Kalam Basigi Lakuang Batinjau}

Ungkapan Tradisional-Sumatera-Minangkabau Aua Kuniang Pasaman Barat.
Rajo Bingkalang, 76, laki-laki

Cerdik Pandai, Minangkabau,

Indonesia.

Aua Kuniang

17 Maret 2016

\section{"Kalam basigi, lakuang batinjau" \\ "Kelam diterangi, lengkung ditinjau" \\ "Kelam terangi, lengkung tinjau"}

Seksama dalam memperhatikan, cermat dan teliti dalam memilah dan memilih serta senantiasa berhati-hati dalam bertindak, merupakan nilai budaya Minangkabau yang terefleksi dalam ungkapan "kalam basigi, lakuang batinjau”. Menurut maestro, nilai budaya tersebut merupakan syarat penting yang mesti menjadi karakter kepribadian setiap orang dalam menggapai kesuksesan.

Relefansi nilai budaya sebagaimana terdapat pada ungkapan "kalam basigi, lakuang batinjau" tidak hanya pada satu bidang pekerjaan yang dilakoni oleh seorang warga. Untuk seluruh bidang pekerjaan nilai budaya tersebut penting untuk dimiliki setiap warga serta dipraktikkan dalam kehidupan. Tidak juga hanya dimiliki oleh warga yang mengemban tugas dan tanggung jawab berdasarkan jabatan tertentu, nlai budaya tersebut harus pula tumbuh subur dalam sanubari masyarakat awam sekalipun.

Ungkapan "kalam basigi lakuang batinjau”, berdasarkan penjelasan maestro juga mengisyaratkan pentingnya upaya maksimal dalam melakukan suatu pekerjaan. Ungkapan tersebut juga mengajak setiap orang untuk terus menggali potensi serta dengan segala kerendahan hati bersedia memanfaatkan segala sumber daya yang tersedia. Berbagai rintangan yang ada serta keterbatasan yang dimilki harus disikapi secara bijak, sehingga tidak mudah berputus asa atau terburu-buru mengambil kesimpulan.

Ungkapan "kalam basigi” menganjurkan agar setiap orang memanfaatkan berbagai alat dan fasilitas yang tersedia dalam menuntaskan sebuah pekerjaan. Selanjutnya, ungkapan "lakuang batinjau" menyuruh agar setiap orang tidak mudah menyerah karena berhadapan dengan situasi yang sulit. Pekerjaan dan permasalahan sesulit dan seberat apapun tetap mesti dituntaskan serta diupayakan jalan keluarnya. Pekerjaan yang berat serta tidak didukung oleh situasi yang kondusif merupakan tantangan yang mesti dihadapi dengan penuh semangat.

Hasanadi, 37, Minang, laki-laki.

Komplek MGS III Blok C No. 1, Gunung Sarik, Padang. 


\section{Ungkapan Tasingguang Labiah Bak Kanai}

Ungkapan Tradisional-Sumatera-Minangkabau Aua Kuniang Pasaman Barat.
Dt. Rky Basa, 54, laki-laki

KAN, Minangkabau,

Indonesia.

Aua Kuniang

17 Maret 2016

\section{"Tasingguang labiah bak kanai" "Tersinggung lebih daripada kena" \\ "Terentuh serasa lebih daripada kena"}

Berdasarkan cerita maestro, rasa kecewa, sakit hati dan terluka yang disebabkan oleh orang lain serta dinilai tidak beralasan, sehingga sayogianya tidak menjadi permasalahan, merupakan penjelasan sederhana terkait ungkapan "tasingguang labiah bak kanai”. Menurut maestro, biasanya perasaan-perasaan tersebut dialami oleh seorang warga yang secara kepribadian dianggap memang bermasalah.

Dalam pemahaman warga Aua Kuniang, pribadi yang dimaksud oleh ungkapan memiliki sensitifitas kepribadian yang berlebihan, sehingga cenderung cepat marah dan tersinggung oleh persoalan atau kejadian yang sebenarnya sangat biasa dan sederhana. Oleh karena itu, biasanya terhadap pribadi yang memiliki kecenderungan kepribadian dimaksud, warga nagari ini memilih untuk menjaga sikap dan jarak, sehingga permasalahan dapat diminimalisir.

Ungkapan "tasingguang labiah bak kanai", biasa diperuntukkan kepada pribadi anggota masyarakat yang cepat marah atau tersinggung karena alasan-alasan sepele. Oleh karena itu, dalam perspektif pentingnya pengajaran nilai Budaya Minangkabau melalui media ungkapan tradisional, paling tidak ungkapan ini mengajarkan dua hal. Partama, ungkapan ini mengajarkan perlunya penanaman nilai-nilai toleran dan lapang dada dalam menyikapi setiap peroalan yang muncul dalam konteks komunikasi dan hubungan saling kait di tengah pergaulan hidup bermasyarakat.

Setiap anggota masyarakat mesti menyadari bahwa bergaul merupakan salah satu media sosialisasi dalam upaya menjalin silaturahmi antar sesama. Pergaulan yang baik sekaligus merupakan peluang bagi setiap anggota masyarakat untuk mendapatkan banyak alternatif dalam upaya menuntaskan berbagai persoalan yang dihadapi. Pada konteks itu, berarti setiap anggota masyarakat yang terlalu sensitif, sehingga kepada diperuntukkan ungkapan "tasingguang labiah bak kanai", dalam pergaulan akan kehilangan kesempatan serta peluang untuk berbagi persoalan dengan orang lain.

Kedua, ungkapan "tasingguang labiah bak kanai” juga mengajarkan kepada masyarakat agar arif dan bijak dalam menyikapi perbedaan kepribadian dari setiap orang. Setiap pribadi dilahirkan serta tumbuh dalam keluarga serta sosial budaya yang relatif tidak sama, sehingga memungkinkan untuk juga memiliki kpribadian yang berbeda satu sama lain. Oleh karena itu, setiap warga masyarakat tentunya harus memiliki pengetahuan serta keluesan mental yang lebih dalam memperlakukan orang lain secara tepat dan proporsional, sehingga kehadirannya berterima secara sosial oleh setiap kalangan. 
Ketidakmampuan dalam melahirkan sikap yang tepat serta proporsional dalam bergaul dengan orang lain yang berbeda kecenderungan kepribadian akan memicu munculnya berbagai persoalan. Sikap kompromi antar warga yang berbeda sistem sosial budaya atau berbeda kepribadian yang dimunculkan melalui sikap dan perilaku di tengah masyarakat sangat diperlukan.

Maestro menambahkan bahwa ungkapan "tasingguang labiah bak kanai” sesungguhnya tidak hanya dikenal secara khusus di Pasaman Barat. Ungkapan tradisional Minangkabau ini juga dikenal pada banyak daserah lain. Di daerah tigo luhak misalnya, Luhak Tanah Datasecara administrasi pemerintahan merupakan wilayah Kabupaten Tanah Datar, Luhak Agamsecara administrasi merupakan wilayah Kabupaten agam dan Luhak Limopuluah—secara administrasi merupakan wilayah Kabupaten Limapuluh Kota, ungkapan ini juga dikenal secara baik. Dengan kata lain, masyarakat Minangkabau di Sumatera Barat secara umum mengenal ungkapan "tasingguang labiah bak kanai". Perbedaan yang akan muncul paling disebabkan oleh berbedanya sistem sosial pada setiap daerah, sehingga relefansi penggunaan ungkapan juga akan mengalami perbedaan dengan sendirinya. Setiap daerah akan memunculkan kekhasannya masing-masing.

Hasanadi, 37, Minang, laki-laki.

Komplek MGS III Blok C No. 1, Gunung Sarik, Padang.

\section{Ungkapan Nak Muliya Tape'i Janji}

Ungkapan Tradisional-Sumatera-Minangkabau Aua Kuniang Pasaman Barat.
Dt. Rky Basa, 54, laki-laki

KAN, Minangkabau, Indonesia.

Aua Kuniang

17 Maret 2016

\section{"Nak muliya tape'i janji" \\ "Agar muliya tepati janji" \\ "Agar dianggap muliya tepati janjii"}

Berakhlak mulia serta dikenal sebagai pribadi yang baik merupakan dambaan setiap orang. Berkenaan dengan itu, kemuliaan seseorang ternyata tidak selamanya ditentukan oleh banyaknya harta yang dimiliki. Kemuliaan seseorang juga tidak selamanya tergantung pada tingginya jabatan yang disandang serta besarnya kewenangan yang bisa digunakan untuk memerintah orang lain.

Tidak jarang justru, orang-orang yang memiliki harta yang banyak dan pangkat yang tinggi, tidak mampu tampil menjadi pribadi yang berakhlak mulia di tengah masyarakat. Sebaliknya, banyak kasus yang kemudian menjadi bukti bahwa masyarakat justru tidak menyematkan penghargaan kepada seorang warga yang dari aspek kekayaan dan jabatan memiliki banyak kelabihan dibandingkan orang lain. Penghargaan tersebut justru diberikan pada pribadi sederhana, berasal dari keluarga yang tidak berharta serta tidak pula memiliki jabatan strategis tertentu di masyarakat. 
Ungkapan "nak muliya tapei janji” (agar mulia tepati janji), sebagaimana dijelaskan oleh maestro, merupakan bukti bahwa ukuran mulia atau tidaknya seseorang sesungguhnya sangat ditentukan oleh pilihan sikap dan perilaku positif yang diambil. Ungkapan tradisional Minangkabau yang dikenal secara luas pada banyak daerah di Sumatera Barat ini juga diapresiasi serta digunakan oleh masyarakat Aua Kuniang Pasaman Barat.

Terutama bagi masyarakat Pasaman Barat, melalui ungkapan "nak muliya tapei janji" terefleksi paradigma berpikir bahwa komitmen seseorang dalam menepati janji ketika dia berjanji merupakan prasyarat penting agar memiliki akhlak yang mulia serta kemudian dimuliakan oleh orang banyak. Masyarakat Pasaman Barat begitu menghargai serta menghormati orang-orang yang mampu menepati janji ketika dia berjanji. Sebaliknya, masyarakat yang mendiami salah satu daerah rantau luhak nan tigo ini begitu antipati terhadap orang-orang yang hanya mampu mengumbar janji namun tidak mampu untuk menepati.

Sebagai media pewarisan nilai budaya Minangkabau, ungkapan "nak muliya tapei janji” mengajarkan pentingnya kemitmen setiap orang untuk bersedia menepati janji-janjinya. Di samping itu, ungkapan tersebut juga memberi pesan kepada masyarakat agar senantiasa berhatihati dalam menjaga lisan serta tidak mudah berjanji kepada orang lain. Pesan moral ini tentunya lahir sebagai satu konsekuensi pengalaman hidup bahwa menepati janji bukanlah persoalan sederhana yang dengan mudah dapat dilakukan.

Janji adalah hutang yang mesti dibayarkan dan menepati janji tidak pernah semudah mengucapkan sebuah janji. Betapa banyak anggota masyarakat yang dengan begitu mudahnya berjanji karena kepentingan tertentu dan begitu banyak cerita kecewa karena banyaknya orang yang tersakiti karena merasa telah ditipu oleh orang lain. Oleh karena itu, membiasakan diri sedari kecil untuk senantiasa menepati janji ketika berjanji merupakan pilihan sikap yang baik. Kebiasaan baik yang apabila telah tertanam sejak kecil akan mengantarkan masyarakat Minangkabau, di Pasaman Barat khususnya, tampil sebagai pribadi dan kelompok sosial yang berakhlak muliya serta dikenal muliya pula oleh orang lain.

Hasanadi, 37, Minang, laki-laki.

Komplek MGS III Blok C No. 1, Gunung Sarik, Padang.

\section{Ungkapan Nak Taguah Paham Dikunci}

Ungkapan Tradisional-Sumatera-Minangkabau Aua Kuniang Pasaman Barat.
Dt. Rky Basa, 54, laki-laki

KAN, Minangkabau,

Indonesia.

Aua Kuniang

17 Maret 2016

"Nak taguah paham dikunci"

"Agar teguh paham dikunci"

"Agar teguh pemahaman dijaga" 
Keteguhan dalam berprinsip serta senantiasa berhati-hati dalam menjaga amanah merupakan pesan moral budaya Minangkabau yang secara implisit terdapat pada ungkapan "nak taguah paham dikunci". Menurut maestro, keteguhan prinsip merupakan kekuatan batin yang akan membantu setiap pribadi anggota satu kelompok masyarakat berhasil dalam menghadapi setiap persoalan yang muncul.

Melalui ungkapan "nak taguah paham dikunci" juga terindikasi secara kuat bahwa keteguhan hati yang dimiliki oleh seseorang sangat ditentukan oleh mampu tidaknya dia dalam menjaga sikap dan perilaku dalam menjalin hubungan dengan orang lain. Konsekuen dalam bersikap serta tidak mudah terpengaruh oleh bujuk rayu orang lain, sehingga tanpa sadar terjerambab menjadi pribadi yang bermental labil, sekaligus merupakan ciri dari setiap pribadi yang memiliki keteguhan prinsip hidup.

Ungkapan tradisional Minangkabau “nak taguah paham dikunci” juga digunakan serta diapresiasi secara baik oleh masyarakat Aua Kuniang Pasaman Barat. Penggunaan ungkapan tersebut tidak selamanya ditemukan dalam situasi resmi bernuansa adat. Ungkapan itu juga dipakai dalam suasana yang santai dalam tindak komunikasi yang berlangsung antara dua orang atau lebih.

Menurut maestro, biasanya ungkapan ini digunakan oleh masyarakat Aua Kuniang Pasaman Barat yang berasal dari status sosial tertentu, seperti dari kalangan ninik mamak dan kalangan cerdik pandai. Artinya, ungkapan ini lebih akan sering digunakan oleh mereka yang memiliki pengetahuan yang luas tentang adat dan budaya Minangkabau serta mengenal dan memahami secara baik arti pentingnya kejelasan sikap dalam berbagai persoalan yang mengemuka di tengah masyarakat.

Maestro meyakinkan bahwa mereka yang teguh dalam berprinsip serta senantiasa mampu menjaga sikap dan perbuatan dalam upaya mempertahankan prinsip yang dimiliki biasanya tidak akan mudah goyah serta kemudian berubah disebabkan oleh munculnya hal baru yang bersifat lebih menggiurkan. Mereka yang teguh dalam berprinsip adalah orang-orang yang telah memililki kestabilan emosi dan kecakapan dalam bersikap sehingga tidak serta merta terombangambing dalam menghadapi rongrongan permasalahan.

Secara sosial budaya Minangkabau, sebagaimana dipraktikkan oleh masyarakat Aua Kuniang Pasaman Barat, penggunaan ungkapan "nak taguah paham di kunci” biasa dilakukan sebagai satu bentuk kritik dan nasehat kepada orang lain. Oleh karena itu, penggunaan ungkapan ini dalam satu tindak komunikasi yang tengah berlangsung, sekaligus membuktikan bahwa masyarakat Pasaman Barat memiliki solidaritas sosial yang baik. Si pengguna ungkapan secara tidak langsung ingin mengatakan bahwa dia adalah bagian tidak terpisahkan dengan orangorang yang sedang terlibat komunikasi dengannya, meskipun mereka tidak terikat hubngan darah dan kekerabatan. Oleh karena itu, sebagai bagian tidak terpisahkan dengan orang lain, dia ikut bertanggung jawab dengan banyak hal yang akan menimpa orang-orang tersebut.

Baik buruknya setiap kejadian yang menimpa orang lain adalah hal yang akan menyenangkan dan sebaliknya akan menyakitkan serta akan ikut dirasakan oleh si pengguna 
ungkapan. Mereka yang terlibat dalam tindak komunikasi dan interaksi ketika ungkapan "nak taguah paham dikunci” dipakai adalah saudara yang akan saling mengkritik dikala tersalah dan akan saling nasehat-menasehati dikala lupa. Baik dikala senang terebih disaat kesusahan. Akhirnya, sebagai kritik maupun nasehat, intensitas penggunakan ungkapan "nak taguah paham dikunci" akan ikut menentukan baik tidaknya hubungan interaktif masyarakat sosial budaya Minangkabau di Pasaman Barat khususnya.

Hasanadi, 37, Minang, laki-laki.

Komplek MGS III Blok C No. 1, Gunung Sarik, Padang.

\title{
9. Ungkapan Bak Paneh dalam Baluka
}

Ungkapan Tradisional-Sumatera-Minangkabau Aua Kuniang Pasaman Barat.

\author{
Dt. Rky Basa, 54, laki-laki \\ KAN,Minangkabau, \\ Indonesia. \\ Aua Kuniang \\ 17 Maret 2016
}

\section{"Bak paneh dalam baluka" \\ "Bak panas dalam belukar" \\ "Bagai panas dalam belukar"}

Hawa panas, baik disebabkan oleh karena terbakar maupun disebabkan oleh teriknya cahaya matahari, yang ada pada satu semak belukar hanya bisa dirasakan dan sulit untuk dilihat. Hawa panas tersebut akan makin terasa bila seseorang masuk ke dalam belukar. Oleh karena itu, penggambaran sesuatu yang tidak tampak secara jelas, biasanya sebuah kejadian buruk yang tertutup oleh berbagai penghalang, namun dampaknya dapat dirasakan dari jarak yang relatif jauh terefleksi melaluai ungkapan "bak paneh dalam baluka".

Menurut maestro, ungkapan "bak paneh dalam baluka” menjelaskan suasana batin seseorang yang tengah bergejolak karena memendam amarah. Secara kasat mata kemarahan yang tersimpan di hati barangkali tidak akan dapat dilihat dengan hanya memperhatikan wajah dan penampilan seseorang. Namun demikian, segala akibat yang dapat dimunculkan akibat suasana hati yang marah akan dapat dirasakan tidak hanya oleh orang yang bersangkutan namun juga oleh orang-orang yang ada disekitarnya.

Ungkapan "bak paneh dalam baluka” biasa digunakan oleh masyarakat Minangkabau, khususnya oleh warga Nagari Aua Kuniang Pasaman Barat. Menurut maestro, penggunaan ungkapan tersebut biasa muncul dalam keseharian warga di daerah ini. Pengguna ungkapan biasanya pula merupakan warga yang berusia di atas 40 tahun. Khusus dikalangan generasi muda yang lahir di atas tahun 70-han, pengguna ungkapan ini sudah jarang ditemukan.

Generasi muda lebih memilih untuk menggunakan kata atau klalimat langsung bermakna denotatif dalam berkomunikasi di antara mereka. Meskipun sebagian kecil mereka memahami maksud ungkapan tersebut namun telah menjadi kelaziman untuk lebih memilih berbagai bentuk 
ungkapan baru. Perkembangan pola pikir disebabkan oleh kemajuan ilmu pengetahuan dan teknologi disinyalir sebagai faktor penting yang menyebabkan semakin asingnya penggunaan ungkapan tradisional Minangkabau "bak paneh dalam baluka" di kalangan generasi muda Pasaman Barat.

Secara sosial budaya penggunaan ungkapan "bak paneh dalam baluka" berfungsi sebagai alat kontrol di tengah masayarakat. Menurut maestro, ungkapan tersebut biasanya digunakan untuk mengingatkan orang lain berkenaan dengan bahaya yang mungkin akan terjadi disebabkan oleh persoalan-persolan yang sulit untuk diprediksi penyebab dan sumbernya. Persoalan tersebut bisa jadi bersumber dari orang lain yang tampa disengaja telah tersakiti sehingga menyimpan dendam dan sakit hati sejak lama. Permasalahan yang berujung dendam kesumat, akan terus bergelora"bak paneh dalam baluka", tidak hanya akan membakar pemiliknya. Akibat buruk dari dendam dan amarah tersebut pada saatnya akan ikut membakar serta menghanguskan orang-orang yang berada disekitarnya.

Diperlukan sikap yang bijak dalam menyikapi setiap akibat yang mungkin saja akan ditimbulkan oleh pilihan sikap dan perilaku dalam bergaul dengan orang lain. Lebih dari itu, penting kiranya kehati-hatian dalam menjaga perasaan setiap orang, sekaligus kewaspadaan dalam mengantisipasi dampak buruk yang dimunculkan oleh setiap orang lain yang pernah bergaul dengan kita, meskipun itu berlangsung pada masa lampau yang jauh. Ketidakcermatan dalam bersikap dan berperilaku serta ketidakwaspadaan dalam mengantisipasi akibat buruk dalam pergaulan akan mendatangkan banyak marabahaya yang akan menghanguskan jalinan tali silaturahmi antar anggota masyarakat.

Hasanadi, 37, Minang, laki-laki.

Komplek MGS III Blok C No. 1, Gunung Sarik, Padang.

\section{Ungkapan Bak Mandi di anak Sungai}

Ungkapan Tradisional-Sumatera-Minangkabau Rajo Bingkalang, 76, laki-laki

Aua Kuniang Pasaman Barat.

Cerdik Pandai, Minangkabau,

Indonesia.

Aua Kuniang

17 Maret 2016

\section{"Bak mandi di anak sungai" \\ "Bak mandi di air sungai" \\ "Bagai mandi di air sungai"}

Menurut maestro terdapat dua fersi pemahaman yang dimiliki oleh masyarakat Nagari Aua Kuniang Pasaman Barat terkait penggunaan ungkapan "bak mandi di anak sungai". Pertama, ungkapan tersebut dipahami sebagai bentuk penjelasan tentang diperolehnya suasana baru atau sesuatu yang baru serta dianggap lebih baik dari apa-apa yang telah diperoleh sebelumnya. Biasanya penjelasan tersebut berkenaan dengan terlepasnya seseorang dari belenggu kesusahan. 
Setelah sekian lama mengalami hidup susah maka tanpa disangka-sangka kehidupan mengalami perubahan ke arah yang lebih baik. Rasa dahaga akan datangnya hidup senang tampa berkekurangan telah terobati. Kebahagiaan pun datang menjelang serta mampu mengobati setiap luka yang selama ini dirasakan. Suasana psikologis sebagaimana dirasakan bersama segala perubahan tersebut, bagi masyarakat Aua Kuniang Pasaman Barat, biasanya digambarkan dengan menggunakan ungkapan "bak mandi di anak sungai".

Kedua, ungkapan "bak mandi di anak sungai” juga digunakan oleh masyarakat nagari Aua Kuniang dalam menjelaskan suasana hati yang tidak kunjung terpuaskan. Sebagaimana dijelaskan maestro, bagaikan sesorang musafir yang sedang menikmati sejuknya air sungai yang dingin ketika mandi berendam, maka tentu kesejukan tersebut tidak akan bertahan lama. Suasana damai penuh kesejukan itu paling dirasakan selama tubuh berada di dalam air. Ketika mandi telah selesai dan sang musafir melanjutkan perjalannya, melangkah sendiri di tengah panasnya terik matahari, maka yang ada hanyalah dahaga yang makin akan terasa. Semua rasa sejuk dan damai ketika berendam di air sungai akan berangsur hilang. Untuk sang musafir dengan perjalanan jauhnya yang tersisa hanyalah kebutuhan akan rasa sejuk dan damai yang tidak terpuaskan.

Secara sosial budaya ungkapan "bak mandi di anak sungai" berfungsi sebagai media pengungkapan ekspresi perasaan bahagia yang dialami oleh seseorang. Terlepas dari kenyataan bahwa, apakah kebahagian tersebut bersifat sementara atau selamanya, namun itulah satu bentuk kearifan yang dimiliki oleh masyarakat Aua Kuniang Pasaman Barat. Kecenderungan untuk menggunakan kata-kata atau kalimat yang bermakna kias seakan telah lekat dalam kepribadian masyarakat di daerah ini.

Bahkan, adanya kebiasaan baru di tengah masyarakat khususnya di kalangan generasi muda, pengungkapan perasaan dengan menggunakan kalimat-kalimat langsung bermakna denotatif, dianggap belum berterima dalam berbagai aspek kehidupan. Karena itu pula, penggunaan ungkapan bergenre bahasa Minangkabau ragam adat dalam berbagai prosesi kegiatan sosial kemasyarakatan, dianggap sebagai sesuatu yang menarik dan tetap penting untuk dilakukan. Di samping mencerminkan kepiawaian dalam memilih kata dan kalimat, penggunaan berbagai bentuk ungkapan semisal "bak mandi di anak sungai", sekaligus menggambarkan kearifan masyarakat Minangkabau di Pasaman Barat dalam berkomunikasi antar sesama.

Hasanadi, 37, Minang, laki-laki.

Komplek MGS III Blok C No. 1, Gunung Sarik, Padang.

\section{PENUTUP}

Melalui tulisan yang berfokus menemukenali nilai budaya Minangkabau pada ungkapan tradisional ini disimpulkan sebagai berikut : 
10 (sepuluh) ungkapan yang berhasil didokumentasi serta dijelaskan dalam kaitannya dengan refleksi budaya Minangkabau dalam ungkapan tradisional sebagai berikut : (1) Ungkapan Simpang Tonang tajam sabalah; (2) Ungkapan teleang kupiah Rang Mandiangin; (3) Ungkapan Talu Rancak di labuah; (4) Ungkapan barek sabalah Nak Rang Talu; (5) Ungkapan kalam basigi lakuang batinjau; (6) Ungkapan tasingguang labiah bak kanai; (7) Ungkapan nak muliya tape'i janji; (8) Ungkapan nak taguah paham dikunci; (9) Ungkapan bak paneh dalam baluka; dan (10) Ungkapan bak mandi di anak sungai.

Setiap ungkapan merefleksikan pesan budaya Minangkabau, yaitu : (1) Adil proporsional; (2) Berpikir lurus komprehensif; (3) Pentingnya kesesuaian antara hati dan perbuatan; (4) Berimbang; (5) Teliti dan tuntas; (6) Stabil emosi; (7) Tepat janji; (8) Teguh pendirian; (9) Cerdas lingkungan; dan (10) Beryukur dan berekspresi.

Melalui tulisan ini pula disarankan pentingnya dilakukan kajian lanjutan terhadap ungkapan tradisional Minangkabau yang dimiliki oleh masyarakat Kabupaten Pasaman Barat, khususnya dilakukan pada 9 (sembilan) kecamatan yang lain. Kegiatan pengkajian yang bersifat berkelanjutan seta dilakukan dengan pendekatan keilmuan yang relevan dinilai sebagai bagian dari upaya mengantisipasi agar tidak terkondisinya ungkapan tradisional dimaksud menuju kepunahan generasi penerus yang sadar budaya Minangkabau.

\section{DAFTAR PUSTAKA}

\section{Buku dan Laporan Penelitian}

BPS Kabupaten Pasaman Barat. 2012 Pemda Kabupaten Pasaman Barat.

Asmawi, DR. 2009. Nagari, Desa dan Nagari. Padang :Suka Bina.

Badan Pusat Statistik, Pasaman Barat Dalam AngkaTahun 2005 ( Padang: BPS, 1999).

Danandjaja, James. 1991. Folklor Indonesia : Ilmu Gosip, Dongeng dan Lain-lain. Jakarta : PT Pustaka Utama Grafiti.

Gebu Minang. 2011. Pedoman Pengamalan Adat Basandi Syarak, Syarak Basandi Kitabullah, Syarak Mangato Adat Mamakai, Alam Takambang Jadi Guru. Jakarta : Gebu Minang.

Jamna, Jamaris. 2004. Pendidikan Matrilinial. Padang: Pusat Pengkajian islam dan Minangkabau (Padang : PPIM, 2004).

Pemerintah Nagari Aia Gadang Kecamatan Pasaman Kabupaten Pasaman Barat. 2015. Rencana Pembangunan Jangka Memengah Nagari 2016-2021.

Pemerintah Nagari Lingkuang Aua Kecamatan Pasaman Kabupaten Pasaman Barat. 2015. Rencana Pembangunan Jangka Menengah (RPJM) Nagari 2016-2021.

Moleong. 2009. Metodologi Penelitian Kualitatif. Bandung: PT Remaja Rosdakarya.

Ratna, Nyoman Kutha. 2004. Teori, Metode, dan Teknik Penelitian Sastra. Yokyakarta : Pustaka Pelajar.

Saydam, Gouzali. 2004. Kamus lengkap Bahasa Minang. Padang : PPIM. 
Wiranta, Sukarna. 2007. Analisis Data Kualitiatif. Modul Diklat Fungsional Peneliti Tingkat Pertama. Cibinong : Pusat Pembinaan, Pendidikan dan Pelatihan Peneliti LIPI.

Seno dkk. 2010. Inventarisasi Karya Budaya di Kabupaten Pasaman dan Kabupaten Pasaman Barat Provinsi Sumatera Barat. Laporan Penelitian. Padang: BPSNT.

Satori, Djam'an dkk. 2009. Metodologi Penelitian Kualitatif. Bandung : Alvabeta.

Yondri dkk. Kesenian Ronggeng Pasaman Sebagai Media Pembauran Masyarakat Multietnis di Kabupaten Pasaman Barat. Laporan Penelitian. Padang: BPSNT.

Yunus, Yulizar. 2014. Peranan Tungku Tigo Sajarangan dan Tali Tigo Sapilin dalam Pelaksanaan ABS - SBK (Makalah) Seminar Penguatan Peranan Tungku Tigo Sajarangan dan Tali Tigo Sapilin dalam Pelaksanaan ABS - SBK, pada tanggal 7 Mei 2014

\section{Sumber Internet}

1. https://mozaikminang.wordpress.com/2009/10/15/sekilas-nagari-talu-dan-sinuruik.

2. https://pasamanbarat.wordpress.com/pasaman-barat/

3. http://sphotos.ak.fbcdn.net/hphotos-ak-http://www.antarasumbar.com/berita/134299/titikawal-penyebaran-islam-di-pasaman-barat.html.

4. http://www.kompasiana.com/sulpandri/sejarah-nagari-sungai-aua-kab- pasaman-barat. 